\title{
The Application of Essential Oils in Edible Coating: Case of Study on Two Fresh Cut Products \\ Valeria Rizzo* and Giuseppe Muratore
}

Di3A University of Catania, via Santa Sofia 100, 95123 Catania, Italy

\section{Abstract}

Essentials oils (EOs) among the natural compounds have been extensively investigated in recent years because of their antimicrobial and antioxidant activities. Thanks to their active components EOs can be added directly to the food, incorporated into packaging material, or used in a separate emitter.

\section{Publication History:}

Received: December 18, 2019

Accepted: February 11, 2020

Published: February 13, 2020

\section{Keywords:}

Antioxidants, Edible coating, Food packaging, Nutraceutical, Nutrients, Pathogens films or coatings, from biodegradable materials or biopolymers, on food may reduce the package barrier requirements, incorporating natural bioactive compounds and prolonging shelf life.

Three case study on application of EOs on ready to cook products and on nutritional values were reported: the effects of anti-browning treatments and dipping in locust bean gum edible coating with or without Foeniculum vulgare EO on ready to cook globe artichoke slices; the addition of $0.5 \%$ (v/v) rosemary EO on potato slices packaged in sous vide bags; and the upgrade of the second study was the third on the evaluation on the nutritional content of cooked samples of slices potatoes. Sensory and microbiological data highlighted a good attitude of globe artichoke and potato slices to be processed with the addition of rosemary EO and cooked in sous vide bags. All nutritional components studied were slightly reduced after sous vide cooking. The ascorbic acid as well as total polyphenol content were well preserved after cooking, and the antioxidant activity calculated showed a loss mean value of $48 \%$ among cultivars, so we can conclude that sous vide cooked vegetables in comparison with boiled, steamed, or microwaved tubers retain nearly all their nutritive value.

\section{Introduction}

Essential oils (EOs) were studied in depth in the past years. Already called volatile or ethereal oils they are aromatic oily liquids obtained from different plant material. One of the producing method was first used in the East (Egypt, India and Persia) and their use is mentioned by Greek and Roman historians [1], their history is as old as it is known.

The increasingly important public health issue as well as hygiene and food production techniques, concerning on food safety has meant that research has been moved through new methods of reducing or eliminating food borne pathogens, possibly in combination with existing methods, looking at the consumer attention desiring fewer synthetic food additives and products with a smaller environmental impact.

People demand for the use of natural antimicrobials instead of chemical antimicrobial agents move forward a wide spreading of the use of essential oils as additives in foods [2].

Many papers provided an extensive overview of the published data on the antibacterial activity of those EOs and their components and how they could be considered suitable for application in or on foods, describing also their possible modes of action [3].

Thanks to these previous data is possible to understand which EOs is more suitable for a food product rather than another one. Chemical composition was also extensively studied [4-19] and reported in Table 1. Tests of antimicrobial activity were performed, and most researchers cited the minimum inhibitory concentration (MIC) as a measure of the antibacterial performance of EOs; a selection of MICs for EOs and $\mathrm{EO}$ components tested in vitro against food borne pathogens was presented by Burt [3].

EOs are recognized as GRAS (generally recognized as safe) from Food and Drug Administration of US (FDA), most of the EOs and their components exhibit antibacterial properties, which are chiefly related to phenolic components [12] and consequently they are often used for the inhibition of pathogenic bacteria in foods. The main aromatic components identified in different essential oils as well as bacteria and yeast on which they have an inhibitory effects as reported in previous studies are detailed in Table 1.

Furthermore, due to the over or underuse of antibiotics, there has been a global emergence of multidrug-resistant microorganisms which reduces the efficacy of current antibiotic therapy and results in thousands of death. Indeed, considering last consumer concern on the recent environmental problems, EOs should be considered an excellent ally to reduce food waste, reducing microbial spoilage and increasing the shelf life of many kind of foods. To respond to many consumers' requests to reduce or eliminate the synthetic preservatives, plant derived compounds, such as EOs, are frequently used, often "Corresponding Author: Dr. Valeria Rizzo, Di3A University of Catania, via Santa Sofia 100, 95123 Catania, Italy; E-mail: vrizzo@unict.it

Citation: Rizzo V, Muratore G (2020) The Application of Essential Oils in Edible Coating: Case of Study on Two Fresh Cut Products. Int J Clin Nutr Diet 6: 149. doi: https://doi.org/10.15344/2456-8171/2020/149

Copyright: (C) 2020 Berka et al. This is an open-access article distributed under the terms of the Creative Commons Attribution License, which permits unrestricted use, distribution, and reproduction in any medium, provided the original author and source are credited. 
Citation: Rizzo V, Muratore G (2020) The Application of Essential Oils in Edible Coating: Case of Study on Two Fresh Cut Products. Int J Clin Nutr Diet 6: 149. doi: https://doi.org/10.15344/2456-8171/2020/149

Page 2 of 7

through dipping techniques or, more recently, by including them within plastic materials [20] or in edible coating [21].

Moreover plastic waste is causing a lot of public concern on their disposal, as well as chemicals used in their production, rightly, since food packaging alone contributes to almost $66 \%$ of total packaging wastes by volume in the world. The application of edible films or coatings, from biodegradable materials or biopolymers, on food, may reduce the package barrier requirements improving in such ways recycling process.

Edible packaging is defined as packaging consisting of an edible thin layer coated on a food or placed as a barrier between the food and the surrounding environment [22].

The increasing utilization of such biodegradable materials is linked with a reduction of volume, weight and costs of packaging.
Considering how food undergoes deterioration from chemical and microbiological processes along the food chain production, edible packaging added with EOs could provide several benefits for foods such as preservation, maintaining foods quality and safety.

Fresh-cut products represent a good chance for the food industry to increase market sales with a type of product able to fully respond to the demand for healthy and convenient foods by modern consumers [20]. Minimally processed products are one of the rapid growing sectors in the food industry due to the convenience and nutritional value, but they are far more perishable and have a shorter shelf life of 4-10 days compared to the original raw material [23]; for this reason one of the last application of edible coating in the food sector is linked with the extension of the shelf life (Table 2). Value addition by processing into fresh-cut and minimally processed products is an attractive alternative since consumers will spend less time on food preparation [24]. Moreover, more than 1000 plants have been claimed to offer special

\begin{tabular}{|c|c|c|c|c|c|}
\hline Essential Oil & $\begin{array}{l}\text { Principal } \\
\text { Components }\end{array}$ & $\%$ & References & $\begin{array}{c}\text { Inhibitory Effects } \\
\text { Against Bacteria and } \\
\text { Yeast }\end{array}$ & References \\
\hline \multirow[t]{2}{*}{ Cilantro } & Linalool & $26 \%$ & \multirow[t]{2}{*}{ Delaquis et al., 2002[18] } & & \\
\hline & E-2-Decanal & $20 \%$ & & & \\
\hline Cinnamon & Trans-cinnamaldehyde & $65 \%$ & $\begin{array}{l}\text { Lens-Lisbonne et al., } \\
\text { 1987[5] }\end{array}$ & & \\
\hline \multirow[t]{2}{*}{ Clove } & Eugenol & $75-85 \%$ & \multirow[t]{2}{*}{ Bauer et al., 2001[57] } & \multirow{2}{*}{$\begin{array}{l}\text { E. coli; S. thphimurium; } \\
\text { S. aureus; L. } \\
\text { monocytogenes }\end{array}$} & \multirow{2}{*}{$\begin{array}{l}\text { Farag et al., 1989[58]; Smith- } \\
\text { Palmer et al., 1998[59]; } \\
\text { Hammer et al., 1999[60] }\end{array}$} \\
\hline & Eugenyl acetate & $8-15 \%$ & & & \\
\hline \multirow[t]{2}{*}{ Coriander } & Linalool & $70 \%$ & \multirow[t]{2}{*}{ Delaquis et al., 2002[18] } & & \\
\hline & E-2-Decanal & $3-4 \%$ & & & \\
\hline \multirow[t]{4}{*}{ Oregano } & Carvacrol & Trace- $80 \%$ & $\begin{array}{l}\text { Lawrence, 1984[4]; } \\
\text { Prudent et al., 1995[7] }\end{array}$ & \multirow{4}{*}{$\begin{array}{l}\text { Escherichia coli } \\
\text { S. typhimurium } \\
\text { S. aureus }\end{array}$} & \multirow{4}{*}{$\begin{array}{l}\text { Prudent et al., 1995[7]; } \\
\text { Hammer et al., 1999[60]; Burt } \\
\text { and Reinders, 2003[61] }\end{array}$} \\
\hline & Thymol & Trace- $64 \%$ & $\begin{array}{l}\text { Charai et al., 1996[8]; } \\
\text { Sivropoulou et al., 1996[9] }\end{array}$ & & \\
\hline & g-Terpinene & $2-52 \%$ & $\begin{array}{l}\text { Kokkini et al 1997[10]; } \\
\text { Russo et al., 1998[11] }\end{array}$ & & \\
\hline & $\rho$-Cymene & $52 \%$ & $\begin{array}{l}\text { Daferera et al., } \\
2000[14] ; \text { Demetzos and } \\
\text { Perdetzoglou, 2001[17]; } \\
\text { Marino et al., 2001[13] }\end{array}$ & & \\
\hline \multirow[t]{4}{*}{ Rosemary } & a-Pinene & $2-25 \%$ & \multirow{4}{*}{$\begin{array}{l}\text { Daferera et al., 2000[14]; } \\
\text { Pintore et al., 2002[19] }\end{array}$} & \multirow{4}{*}{$\begin{array}{l}\text { E. coli } \\
\text { S. typhimurium } \\
\text { B. cereus } \\
\text { S. aureus } \\
\text { L. monocytogenes }\end{array}$} & \multirow{4}{*}{$\begin{array}{l}\text { Farag et al., 1989[58]; Smith- } \\
\text { Palmer et al., 1998[59]; } \\
\text { Hammer et al., 1999[60]Pintore } \\
\text { et al., 2002[19]; Chaibi et al., } \\
\text { 1997[62] }\end{array}$} \\
\hline & Bornyl acetate & $0-17 \%$ & & & \\
\hline & Camphor & $2-14 \%$ & & & \\
\hline & 1,8-Cineole & $3-89 \%$ & & & \\
\hline \multirow[t]{5}{*}{ Sage } & Camphor & $6-15 \%$ & \multirow[t]{5}{*}{ Marino et al., 2001[13] } & \multirow{5}{*}{$\begin{array}{l}\text { Escherichia coli } \\
\text { S. thphimurium } \\
\text { S. aureus } \\
\text { L. monocytogenes }\end{array}$} & \multirow{5}{*}{$\begin{array}{l}\text { Shelef et al., 1984[63]; Farag } \\
\text { et al., 1989[58]; Smith-Palmer } \\
\text { et al., 1998[59]; Hammer et al., } \\
\text { 1999[60] }\end{array}$} \\
\hline & a-Pinene & $4-5 \%$ & & & \\
\hline & b-Pinene & $2-10 \%$ & & & \\
\hline & 1,8-Cineole & $6-14 \%$ & & & \\
\hline & a-Tujone & $20-42 \%$ & & & \\
\hline \multirow[t]{4}{*}{ Thyme } & Thymol & $10-64 \%$ & \multirow{4}{*}{$\begin{array}{l}\text { Lens-Lisbonne et al., } \\
\text { 1987[5]; McGimpsey et } \\
\text { al., 1994[6]; Cosentino et } \\
\text { al., 1999[12]; Marino et } \\
\text { al.,1999[13]; Daferera et } \\
\text { al.,2000[14]; Juliano et al., } \\
2000[15]\end{array}$} & \multirow{4}{*}{$\begin{array}{l}\text { E. coli } \\
\text { S. thphimurium } \\
\text { S. aureus } \\
\text { L. monocytogenes }\end{array}$} & \multirow{4}{*}{$\begin{array}{l}\text { Farag et al., 1989[58]; Firouzi } \\
\text { et al., 1998[64]; Smith-Palmer } \\
\text { et al., 1998[59]; Cosentino et } \\
\text { al., 1999[12]; Hammer et al., } \\
\text { 1999[60]; Burt and Reinders, } \\
\text { 2003[61] }\end{array}$} \\
\hline & Carvacrol & $2-11 \%$ & & & \\
\hline & g-Terpinene & $2-31 \%$ & & & \\
\hline & & $10-56 \%$ & & & \\
\hline
\end{tabular}

Table 1: Principal components of essential oils and their inhibitory effects against bacteria and yeast. 
benefits in the treatment of different disease, since dietary bioactive compounds from different functional foods, herbs and nutraceuticals (ginseng, ginkgo, nuts, grains, tomato, soy phytoestrogens, curcumin, melatonin, polyphenols, antioxidant vitamins, etc.) can ameliorate or even prevent diseases. Protection from chronic diseases of aging involves antioxidant activities, mitochondrial stabilizing functions, metal chelating activities, inhibition of apoptosis of vital cells, and induction of cancer cell apoptosis [25].

The term "nutraceutical" was coined in 1989 by the Foundation for Innovation in Medicine (New York, US; they may range from isolated nutrients, dietary supplements to genetically engineered "designer" foods, herbal products and processed products such as cereals, soups and beverages. Among food resources, one of the selected nutritive nutraceuticals are antioxidants [26].

Functional food has one or more compounds with biochemical and physiological functions beneficial to the human health. Anthocyanins, catechins, cyanidins and flavonols, all from food sources, are antioxidant nutraceuticals, that carry out their antioxidant activity by donating electrons and breaking radical-chain reactions, also as inhibition of LDL oxidation and often acting as superoxide scavengers [25].

The opportunity for consumer to find fresh-cut products rich in healthy compounds is very high and continues to grow, develop and evolve to offer new opportunities for new product development and marketing. As said before such products are far more perishable and the interest from researchers is moved to prolong their shelf life adopting integrated approaches.

Several studies have been done to determine the effects of edible coatings on fresh-cut fruit such as mango [27], papaya [28,29], pear [30], banana [31], pineapple [32-35] and strawberry [36] as well as on vegetables as red bell pepper [37].

The incorporation of antimicrobial agents in edible coatings may widen the functionality of coatings in protecting the fresh-cut fruit from microbial spoilage and thus extend their shelf-life [38].

For example, alginate-based edible coating formulation incorporated with $0.3 \%(\mathrm{w} / \mathrm{v})$ lemongrass has potential to extend the shelf-life and maintain the quality of fresh-cut pineapple [39].

Increasing shelf life of fruits and vegetables for reducing postharvest disease and food waste during the supply chain is the main goal for the third millennium. Edible coating allows the opportunity to incorporate natural bioactive compounds as i.e. rosemary extracts that thanks to carnosol and carnosoic acid, inhibit peroxidation of oils operating as antioxidant nutraceuticals [25].

Among antioxidant compounds, EOs has been extensively investigated for their antimicrobial and antioxidant activities. Thanks to their active components EOs can be added directly to the food, enriching it in flavouring compounds, or incorporated into packaging material, or used in a separate emitter.

EOs are volatile, aromatic compounds of leaves, flowers, bark, stems, roots, resin, and seeds. They have many typical characteristics considering that different countries and different seasons give back different chemical composition and thus may exhibit different biological activities [40-43,2].

Additionally, their effect on the control of pathogenic microorganisms in foods is very important and there are many researches on this subject.

The ecological conditions of different countries may influence the chemical profile of the plant materials, because some compounds may be accumulated at a particular period in response to environmental conditions [42-49].

Consumer prefer the use of natural antimicrobials instead of chemical antimicrobial agents.

The emergence of multi-drug resistant strains due to incorrect use and overuse of existing antimicrobials is becoming a formidable threat in the fight against disease. Alternative natural therapies are often used as additional treatment regimens to fight infection.

\section{Experiments}

The globe artichoke is a natural source of minerals, fiber, inulin, and polyphenols, and in recent years its reputation as functional food and its economic value have increased, because inulin was confirmed as reducing blood cholesterol and triglyceride levels and for the ability to oppose the increase of glycemia [50].

A ready-to-cook (RTC) version of this product could improve its commercialization and consumption [21]. The effects of antibrowning treatments (citric acid $0.5 \%+$ ascorbic acid $2 \%$, or cysteine $0.5 \%, \mathrm{w} / \mathrm{v}$ ) and dipping in locust bean gum (LBG) edible coating with or without the addition of Foeniculum vulgare (EO) were studied. Physico-chemical traits, microbiological and sensory descriptors were determined [21].

\begin{tabular}{|l|l|}
\hline \multicolumn{1}{|c|}{ Edible Coating } & \multicolumn{1}{c|}{ Food Applications } \\
\hline Alginate & $\begin{array}{l}\text { Shelf life extension of fresh-cut pineapple[65, 66], guava [67], sauced silver carp [68]; developing an antibacterial } \\
\text { film [69]; fresh-cut cantaloupe [70]; raspberry fruit [71]; fresh fruits [72] }\end{array}$ \\
\hline Chitosan & $\begin{array}{l}\text { Shelf life extension of guava [67]; of strawberries [73]; improve quality of cold-stored cucumber [74]; of raw grass } \\
\text { carp [75]; of lamb meat [76]; }\end{array}$ \\
\hline Locust Bean Gum & Improving postharvest decay of mandarin fruit [77]; quality maintenance of white shrimps [78] \\
\hline Metilcellulose & $\begin{array}{l}\text { Conservation of red guava [79]; of plum [80]; postharvest quality of citrus fruit [81]; Shelf life extension of sauced } \\
\text { silver carp [68]; of walnuts [82]; cold stored grapes [83] }\end{array}$ \\
\hline Pectin & $\begin{array}{l}\text { Minimize post-harvest decay of tomatoes[84]; shelf life extension of strawberry [85]; fresh cut apple [86]; raspberry } \\
\text { fruit [71]; }\end{array}$ \\
\hline
\end{tabular}

Table 2: Edible coating and some applications studied. 
The results showed that, despite the antioxidant treatment used, when EO was added to LBG, all microbiological groups underwent an average reduction of $0.50 \log \mathrm{CFU} \mathrm{g}^{-1}$.

The ability of LBG edible coating with added EO in maintaining microbiological, physical, chemical, and sensory qualities, makes it a promising processing tool for the preservation of RTC globe artichoke slices during storage for 11 days at $4^{\circ} \mathrm{C}[21]$.

The next case was aimed at assessing the suitability of six early potato cultivars, for minimal processing. In particular, the sous vide packaging method and $0.5 \%(\mathrm{v} / \mathrm{v})$ of rosemary essential oil (REO) were evaluated as a strategy for the quality preservation of sliced potatoes. Physical, mechanical, chemical, microbiological and sensory characteristics were monitored [20].

Results demonstrated that the synergic use of REO and sous vide packaging had a positive effect on texture, and limited the growth of mesophilic bacteria (TMB) and Enterobacteriaceae (TEB) over the storage period; it also ensured a certain retention of ascorbic acid (AsAc), total phenol content (TPC) and antioxidant activity (AA).

The proposed technological strategy is a valid solution for the preservation of RTC sliced potatoes, contributing to limit the quality decrease until 11 days of cold storage, for the most suitable cultivars identified (Fontane and Marabel).

The addition of REO significantly $(\mathrm{P} \leq 0.05)$ controlled the growth of TMB and TEB when compared to the relative control samples, although with different efficacy among varieties.

The REO treatment reduced, at the end of storage, TMB counts differently among different $\mathrm{cv}$, with any significant variation in Elodie cv. Conversely, the yeast and mould (YM) population was not affected by EO with the exception of Elodie cv, confirming how said before on different activity respect different microbial population.

Results showed that the synergistic use of REO and vacuum packaging, combined with refrigerated storage, can be a viable strategy for the quality preservation of minimally processed potatoes, intended to be cooked with the sous vide technique [20].

With regard to the sensory analysis, only potato samples without REO showed the negative descriptors off-odors and off-flavors at the end of the considered period, thus highlighting a good attitude of potato slices to be processed with the addition of REO and next cooking in sous vide bags.

The EO addition also ensured a certain retention of AsAc, TPC and AA. Among cultivars, Marabel reported a significantly higher TPC and the lowest reduction for the AsAc level during cold storage, underlining the importance of the cultivar choice as well as the environmental conditions in determining the overall quality of early potato tubers [51].

So, after the previous experiment, we hoped to detect such positive effect played by EOs, also after cooking process in sous vide bags on nutritional compounds.

Almost all information about the main nutrients in foods: AsAc, TPC and AA are often monitored in freshly harvested or in raw food products also in RTC products. So the upgrade of the previous work was to study how the nutritional content was affected by REOs addition and cooking in sous vide bags [52].

The AsAc content was slightly low in all samples, ranging from 4.9 to $3.2 \mathrm{mg} / 100 \mathrm{~g}$ of fresh weight, taking into account that this compound is commonly considered heating sensitive.

In particular, considering how the retention values of boiled tubers ranged from $54 \%$ to $97 \%$, we can affirm that sous vide cooking probably thanks to the additional treatment with REO, better preserve the AsAc keeping values nearest to the raw tubers with moderate loss to a maximum of $20 \%$ in Erika.

TPC is well preserved after cooking, of course the varieties with the highest content are able to save a high amount of the compound studied; the AA was reduced in sous vide cooked potato slices, with a loss mean value of $48 \%$ among cultivars, Fontane showed the highest AA value and Erika the lowest whereas considering the reduction from initial AA on the raw material Elodie kept the highest AA content.

\section{Conclusions}

Considering results obtained from reported experiments and looking towards the aim of most recent papers and projects, some clear evidence are underlined.

In particular the interest in application of edible coating and EOs is increasing; new researches are focused on new methods of application of edible coating like nanoemulsion-based edible coatings enriched in EOs [53-54] as well as pointing out the activity of EOs against new resistant microorganism or against foodborne pathogens [55] and using nanoemulsions which contribute to support the use of EOs in foods [56].

Sure enough the use of EOs in consumer goods is expected to increase in the future due to the rise of 'green consumerism' improving nutritive quality for final consumers.

Results of cited experiments showed that the synergistic use of antioxidant treatment (anti-browning agent) and LBG coating with F. vulgare $\mathrm{EO}$ can be a valid strategy to preserve the quality of RTC globe artichoke slices. The positive and significant effect were on PPO inhibition, texture, color, AsAc, TPC, and AA. When EO was added to LBG, all microbiological groups underwent an appreciable decrease and the overall sensory attributes had the highest score [21].

The synergistic use of REO and vacuum packaging, combined with refrigerated storage, can be a viable strategy for the quality preservation of minimally processed potatoes, intended to be cooked with the sous vide technique. The addition of REO to the fresh-cut product had a positive effect on texture, and on the growth of mesophilic bacteria and Enterobacteriaceae over the storage period, also ensured a certain retention of AsAc, TPC, and AA and also on sensory analysis [20].

Looking at the positive results obtained previously, the synergistic use of REO and vacuum packaging, combined with refrigerated storage had a positive effect on nutritional compounds in minimally processed potatoes. Specifically on AsAc, TPC and AA that were slightly reduced after sous vide cooking. Of course among cultivars studied, exist a natural attitude to be processed and to keep the highest nutritive values. Nutritional characteristics pointed out in the experiment, were kept by the samples, suggesting as more study are 
Citation: Rizzo V, Muratore G (2020) The Application of Essential Oils in Edible Coating: Case of Study on Two Fresh Cut Products. Int J Clin Nutr Diet 6: 149. doi: https://doi.org/10.15344/2456-8171/2020/149

Page 5 of 7

require before EOs and sous vide cooking bags can be reliably used in commercial applications, as well as major investigations should be done on interaction with AsAc in food matrix [52].

Analysis of nutritional characteristics after the application of the different kind of edible coatings available and the enrichment with existing EOs should be improved, further study we'll be extend with these aims on different food materials.

\section{Competing Interests}

The Authors wish to confirm that there are no known conflicts of interest associated with this publication and there has been no significant financial support for this work that could have influenced its outcome.

\section{References}

1. Guenther E (1948) The Essential Oils. D. Van Nostrand Inc, New York.

2. Gouveia AR, Alves M, de Almeida JM, Monteiro-Silva F, González-Aguilar $G$, et al. (2017) The antimicrobial effect of essential oils against Listeria monocytogenes in Sous-vide cook-chill beef during storage. J Food Process Preserv 41: e13066.

3. Burt S (2004) Essential oils: their antibacterial properties and potentia applications in foods. Int J Food Microbiol 94: 223-253.

4. Lawrence BM (1984) The botanical and chemical aspects of oregano Perfumer \& Flavorist 9: 41-51.

5. Lens-Lisbonne C, Cremieux A, Maillard C, Balansard G (1987) Methodes d'evaluation de l'activite' antibacterienne des huiles essentielles: application aux essences de thym et de cannelle. J Pharmacie de Belgique 42: 297-302.

6. McGimpsey JA, Douglas MH, Van Klink JL, Beauregard DA, Perry NB, et al. (1994) Seasonal variation in essential oil yield and composition from naturalized Thymus vulgaris L in New Zealand. Flavour Frag. J. 9: 347-352.

7. Prudent D, Perineau F, Bessiere JM, Michel GM, Baccou JC, et al. (1995) Analysis of the essential oil of wild oregano from Martinique (Coleus aromaticus Benth) evaluation of its bacteriostatic and fungistatic properties. J Essent Oil Res 7: 165-173.

8. Charai M, Mosaddak M, Faid M (1996) Chemical composition and antimicrobial activities of two aromatic plants: Origanum majorana L. and O. compactum Benth. J Essent Oil Res 8: 657-664

9. Sivropoulou A, Papanikolaou E, Nikolaou C, Kokkini S, Lanaras T, et al. (1996) Antimicrobial and cytotoxic activities of Origanum essential oils. Agric Food Chem 44: 1202-1205.

10. Kokkini S, Karousou R, Dardioti A, Krigas N, Lanaras T, et al. (1997) Autumn essential oils of Greek oregano. Phytochemistry 44: 883-886.

11. Russo M, Galletti GC, Bocchini P, Carnacini A (1998) Essential oil chemica composition of wild populations of Italian oregano spice (Origanum vulgare ssp. hirtum (Link) Ietswaart): A preliminary evaluation of their use in chemotaxonomy by cluster analysis: 1 . Inflorescences. J Agric Food Chem 46: $3741-3746$

12. Cosentino S, Tuberoso CIG, Pisano B, Satta M, Mascia V, et al. (1999) In vitro antimicrobial activity and chemical composition of Sardinian Thymus essential oils. Lett Appl Microbiol 29: 130-135.

13. Marino M, Bersani C, Comi G (2001) Impedance measurements to study the antimicrobial activity of essential oils from Lamiacea and Compositae. Int Food Microbiol 67: 187-195

14. Daferera DJ, Ziogas BN, Polissiou MG (2000) GC-MS analysis of essentia oils from some Greek aromatic plants and their fungitoxicity on Penicillium digitatum. J Agric Food Chem 48: 2576-2581.

15. Juliano C, Mattana A, Usai M (2000) Composition and in vitro antimicrobia activity of the essential oil of Thymus herba-barona Loisel growing wild in Sardinia. J Essent Oil Res 12: 516-522.

16. Bauer K, Garbe D, Surburg H (2001) Common Fragrance and Flavor Materials: Preparation, Properties and Uses. Wiley-VCH, Weinheim.

17. Demetzos C, Perdetzoglou DK, Tan K (2001) Composition and antimicrobia studies of the oils of Origanum calcaratum Juss. and O. scabrum Boiss. et Heldr. from Greece. J Essent Oil Res 13: 460-462.
18. Delaquis PJ, Stanich K, Girard B, Mazza G (2002) Antimicrobial activity of individual and mixed fractions of dill, cilantro, coriander and eucalyptus essential oils. Int J Food Microbiol 74: 101-109.

19. Pintore G, Usai M, Bradesi P, Juliano C, Boatto G et al. (2002) Chemical composition and antimicrobial activity of Rosmarinus officinalis $L$ oils from Sardinia and Corsica. Flavour Frag J 17: 15-19.

20. Rizzo V, Amoroso L, Licciardello F, Mazzaglia A, Muratore G, et al. (2018) The effect of sous vide packaging with rosemary essential oil on storage quality of fresh-cut potato. LWT-Food Sci Technol 94: 111-118.

21. Rizzo V, Lombardo S, Pandino G, Barbagallo RN, Mazzaglia A, et al. (2019) Shelf life study of ready to cook slices of globe artichoke 'Spinoso sardo': effects of anti-browning solutions and edible coating enriched with "Foeniculum vulgare" essential oil. J Sci Food Agric 99: 5219-5228.

22. Milani MJ, Maleki G (2012) Hydrocolloids in food industry. Food industrial processes methods and equipment. Croatia: InTech publication.

23. Prakash A, Baskaran R, Paramasivam N, Vadivel V (2018) Essential oil based nanoemulsions to improve the microbial quality of minimally processed fruits and vegetables: A review. Food Res Int 111: 509-523.

24. Rocculi P, Cocci E, Romani S, Sacchetti G, Dalla Rosa M, et al. (2009) Effect of 1-MCP treatment and N2O MAP on physiological and quality changes of fresh-cut pineapple. Postharvest Biol Technol 51: 371-377.

25. Ferrari CKB (2004) Functional foods, herbs and nutraceuticals: towards biochemical mechanisms of healthy aging. Biogerontology 5: 275-289.

26. Andlauer W, Furst $P(2002)$ Nutraceuticals: a piece of history, present status and outlook. Food Res Int 35: 171-176.

27. Chien PJ, Sheu F, Yang FH (2007) Effects of edible chitosan coating on quality and shelf life of sliced mango fruit. J Food Eng 78: 225-229.

28. Tapia MS, Rojas-Graü MA, Carmona A, Rodríguez FJ, Soliva-Fortuny R, et al. (2008) Use of alginate- and gellan-based coatings for improving barrier texture and nutritional properties of fresh-cut papaya. Food Hydrocolloids 22: 1493-1503.

29. Brasil IM, Gomes C, Puerta-Gomez A, Castell-Perez ME, Moreira RG, et al. (2012) Polysaccharide-based multilayered antimicrobial edible coating enhances quality of fresh-cut papaya. LWT-Food Sci Technol 47: 39-45.

30. Oms-Oliu G, Soliva-Fortuny R, Martín-Belloso O (2008) Edible coatings with antibrowning agents to maintain sensory quality and antioxidant properties of fresh-cut pears. Postharvest Biol Technol 50: 87-94.

31. Bico SLS, Raposo MFJ, Morais RMSC, Morais AMMB (2009) Combined effects of chemical dip and/or carrageenan coating and/or controlled atmosphere on quality of fresh-cut banana. Food Control 20: 508-514.

32. Montero-Calderón M, Rojas-Graü MA Martín-Belloso O (2008) Effect of packaging conditions on quality and shelf-life of fresh-cut pineapple (Ananas comosus). Postharvest Biol Technol 50: 182-189.

33. Bierhals VS, Chiumarelli M, Hubinger MD (2011) Effect of cassava starch coating on quality and shelf life of fresh-cut pineapple (Ananas Comosus L Merril cv "Pérola"). J Food Sci 76: 62-72.

34. Azarakhsh N, Osman A, Ghazali HM, Tan CP, Mohd Adzahan N, et al. (2012) Optimization of alginate and gellan-based edible coating formulations for fresh-cut pineapples. Int Food Res J 19: 279-285.

35. Mantilla N, Castell-Perez ME, Gomes C, Moreira RG (2013) Multilayered antimicrobial edible coating and its effect on quality and shelf-life of freshcut pineapple (Ananas comosus). LWT Food Sci Technol 51: 37-43.

36. Maher ZE, Entsar SA (2013) Chitosan based edible films and coatings: A review. Materials Science and Engineering: C 33: 1819-1841.

37. Poverenov E, Zaitsev Y, Arnon H, Granit R, Alkalai-Tuvia S, et al. (2014) Effects of a composite chitosan-gelatin edible coating on postharvest quality and storability of red bell peppers. Postharvest Biol Technol 96: 106-109.

38. Raybaudi-Massilia RM, Mosqueda-Melgar J, Martín-Belloso O (2008) Edible alginate-based coating as carrier of antimicrobials to improve shelf-life and safety of fresh-cut melon. Int J Food Microbiol 121: 313-327.

39. Azarakhsh N, Osman A, Ghazali HM, Tan CP, Adzahan NM (2014) Lemongrass essential oil incorporated into alginate-based edible coating for shelf-life extension and quality retention of fresh-cut pineapple. Postharvest Biol Technol 88: 1-7.

40. Gachkar L, Yadegarı D, Rezaeı MB, Taghızadeh M, Astaneh SA, et al. (2007) Chemical and biological characteristics of Cuminum cyminum and Rosmarinus officinalis essential oils. Food Chem 102: 898-904. 
Citation: Rizzo V, Muratore G (2020) The Application of Essential Oils in Edible Coating: Case of Study on Two Fresh Cut Products. Int J Clin Nutr Diet 6: 149. doi: https://doi.org/10.15344/2456-8171/2020/149

Page 6 of 7

41. Nezhadali A, Nabavı M, Rajabıan M, Akbarpour M, Pouralı P, et al. (2014) Chemical variation of leaf essential oil at different stages of plant growth and in vitro antibacterial activity of Thymus vulgaris Lamiaceae, from Iran. Beni-Suef University Journal of Basic and Applied Sciences 3: 87-92.

42. Teixeira B, Marques A, Ramos C, Neng NR, Nogueira JM, et al. (2013) Chemical composition and antibacterial and antioxidant properties of commercial essential oils. Ind Crop Prod 43: 587-595.

43. Azeredo DGA, Stamford TLM, Nunes PC, Neto NJG, De Oliveira MEG, et al. (2011) Combined application of essential oils from Origanum vulgare L. and Rosmarinus officinalis L. to inhibit bacteria and autochthonous microflora associated with minimally processed vegetables. Food Res Int 44: 15411548.

44. Khalil N, Ashour M, Fikry S, Singab AN, Salama O, et al. (2018) Chemica composition and antimicrobial activity of the essential oils of selected Apiaceous fruits. Future J Pharmac Sci 4: 88-92.

45. Tosun QY, Üçok Alakavuk D, Ulusoy D, Erkan N (2018) Effects of essentia oils on the survival of Salmonella Enteritidis and Listeria monocytogenes on fresh Atlantic salmons (Salmo salar) during storage at $2 \pm 1{ }^{\circ} \mathrm{C}$. J Food Safety 38: 12408 .

46. De Medeiros Barbosa I, da Costa Medeiros JA, de Oliveira KÁR, Gomes Neto NJ, Tavares JF, et al. (2016) Efficacy of the combined application of oregano and rosemary essential oils for the control of Escherichia coli Listeria monocytogenes and Salmonella Enteritidis in leafy vegetables. Food Contr 59: 468-477.

47. Ghabraie M, Vu KD, Tata L, Salmieri S, Lacroix M, et al. (2016) Antimicrobial effect of essential oils in combinations against five bacteria and their effect on sensorial quality of ground meat. LWT- Food Sci Technol 66: 332-339.

48. Pesavento G, Calonico C, Bilia AR, Barnabei M, Calesini F, et al (2015) Antibacterial activity of Oregano, Rosmarinus and Thymus essential oils against Staphylococcus aureus and Listeria monocytogenes in bee meatballs. Food Contr. 54: 188-199.

49. Mazzarrino G, Paparella A, Chaves-López C, Faberi A, Sergi M, et al (2015) Salmonella enterica and Listeria monocytogenes inactivation dynamics after treatment with selected essential oils. Food Contr 50: 794-803.

50. Lattanzio V, Kroon PA, Linsalata V, Cardinali A (2009) Globe artichoke: a functional food and source of nutraceutical ingredients. J Functional Foods 1: $131-144$

51. Lombardo S, Pandino G, Mauromicale G (2017) The effect on tuber quality of an organic versus a conventional cultivation system in the early crop potato. J Food Comp Anal 62: 189-196.

52. Amoroso L, Rizzo V, Muratore G (2019) Nutritional values of potato slices added with rosemary essential oil cooked in sous vide bags. Int J Gastron Food Sci 15: 1-5.

53. Artiga-Artigas $M$, Acevedo-Fani A, Martín-Belloso O (2017) Improving the shelf life of low-fat cut cheese using nanoemulsion-based edible coatings containing oregano essential oil and mandarin fiber. Food Cont 76: 1-12.

54. Noori S, Zeynali F, Almasi H (2018) Antimicrobial and antioxidant efficiency of nanoemulsion-based edible coating containing ginger (Zingibe officinale) essential oil and its effect on safety and quality attributes of chicken breast fillets. Food Control 84: 312-320.

55. Azevedo AN, Buarque PR, Cruz EMO, Fitzgerald Blank A, Alves PB, et a (2014) Response surface methodology for optimisation of edible chitosan coating formulations incorporating essential oil against several foodborne pathogenic bacteria. Food Cont 43: 1-9.

56. Donsì F, Ferrari G (2016) Essential oil nanoemulsions as antimicrobial agents in food. J Biotec 233: 106-120.

57. Bauer K, Garbe D, Surburg H (2001) Common Fragrance and Flavor Materials: Preparation, Properties and Uses. Wiley-VCH, Weinheim.

58. Farag RS, Daw ZY, Hewedi FM, El-Baroty GSA (1989) Antimicrobial activity of some Egyptian spice essential oils. J Food Protection 52: 665-667.

59. Smith-Palmer A, Stewart J, Fyfe L (1998) Antimicrobial properties of plant essential oils and essences against five important food-borne pathogens. Lett Appl Microbiol 26: 118-122.

60. Hammer KA, Carson CF, Riley TV (1999) Antimicrobial activity of essential oils and other plant extracts. J Appl Microbiol 86: 985-990.

61. Burt SA, Reinders RD (2003) Antibacterial activity of selected plant essentia oils against Escherichia coli O157:H7. Lett Appl Microbiol 36: 162-167.
62. Chaibi A, Ababouch LH, Belasri K, Boucetta S, Busta FF, et al. (1997) Inhibition of germination and vegetative growth of Bacillus cereus $T$ and Clostridium botulinum 62A spores by essential oils. Food Microbiol. 14: 161-174.

63. Shelef LA, Jyothi EK, Bulgarelli MA (1984) Growth of enteropathogenic and spoilage bacteria in sage-containing broth and foods. J Food Sci 49: 737740 .

64. Firouzi R, Azadbakht $M$, Nabinedjad A (1998) Anti-listerial activity of essential oils of some plants. J Applied Animal Res 14: 75-80.

65. Azarakhsh N, Osman A, Ghazali HM, Tan Chin P, Adzahan NM, et al. (2014) Lemongrass essential oil incorporated into alginate-based edible coating for shelf life extension and quality retention of fresh-cut pineapple. Postharvest Biol Technol 88: 1-7.

66. Prakash A, Baskaran R, Vadivel V (2020) Citral nanoemulsion incorporated edible coating to extend the shelf life of fresh cut pineapples. LWT 118: 108851.

67. Arroyo BJ, Bezerra AC, Oliveira LL, Arroyo SJ, Almeida de Melo E, et al. (2020) Antimicrobial active edible coating of alginate and chitosan add $\mathrm{ZnO}$ nanoparticles applied in guavas (Psidium guajava L.). Food Chemistry 309: 125566.

68. Rezaei F, Shahbazi Y (2018) Shelf-life extension and quality attributes of sauced silver carp fillet: A comparison among direct addition, edible coating and biodegradable film. LWT 87: 122-133.

69. Zhang W, Shu C, Chen Q, Cao J, Jiang W, et al. (2019) The multi-layer film system improved the release and retention properties of cinnamon essential oil and its application as coating in inhibition to penicillium expansion of apple fruit. Food Chem 299: 125109.

70. Sarengaowa, Hu W, Feng K, Xiu Z, Jiang A, et al. (2019) Thyme oil alginatebased edible coatings inhibit growth of pathogenic microorganisms spoiling fresh-cut cantaloupe. Food Bioscience 32: 100467.

71. Guerreiro AC, Gago CML, Faleiro ML, Miguel MGC, Antunes MDC, et al. (2015) Raspberry fresh fruit quality as affected by pectin- and alginatebased edible coatings enriched with essential oils. Scientia Horticulturae 194: 138-146

72. Guerreiro AC, Gago CML, Faleiro ML, Miguel MGC, Antunes MDC, et al (2015) The effect of alginate-based edible coatings enriched with essential oils constituents on Arbutus unedo L. fresh fruit storage. Postharvest Biol Technol 100: 226-233.

73. Hajji S, Younes I, Affes S, Boufi S, Nasri M, et al. (2018) Optimization of the formulation of chitosan edible coatings supplemented with carotenoproteins and their use for extending strawberries postharvest life. Food Hydrocolloids 83: 375-392.

74. Istúriz-Zapata MA, Hernández-López M, Correa-Pacheco ZN, Barrera-Necha LL (2020) Quality of cold-stored cucumber as affected by nanostructured coatings of chitosan with cinnamon essential oil and cinnamaldehyde. LWT 123: 109089.

75. Yu D, Xu Y, Regenstein JM, Xia W, Yang F, et al. (2018) The effects of edible chitosan-based coatings on flavor quality of raw grass carp (Ctenopharyngodon idellus) fillets during refrigerated storage. Food Chem 242: 412-420.

76. Pabast M, Shariatifar N, Beikzadeh S, Jahed G (2018) Effects of chitosan coatings incorporating with free or nano-encapsulated Satureja plant essential oil on quality characteristics of lamb meat. Food Control 91: 185192.

77. Parafati L, Vitale A, Restuccia C, Cirvilleri G (2016) The effect of locust bean gum (LBG)-based edible coatings carrying biocontrol yeasts against Penicillium digitatum and Penicillium italicum causal agents of postharvest decay of mandarin fruit. Food Microbiol 58: 87-94.

78. Licciardello F, Kharchoufi S, Muratore G, Restuccia C (2018) Effect of edible coating combined with pomegranate peel extract on the quality maintenance of white shrimps (Parapenaeus longirostris) during refrigerated storage. Food Pack Shelf Life 17: 114-119.

79. Formiga AS, Pinsetta JSJ, Pereira EM, Cordeiro INF, Mattiuz BH, et al. (2019) Use of edible coatings based on hydroxypropyl methylcellulose and beeswax in the conservation of red guava 'Pedro Sato'. Food Chem 290: 144-151.

80. Choi WS, Singh S, Lee YS (2016) Characterization of edible film containing essential oils in hydroxypropyl methylcellulose and its effect on quality attributes of 'Formosa' plum (Prunus salicina L.). LWT 70: 213-222. 
Citation: Rizzo V, Muratore G (2020) The Application of Essential Oils in Edible Coating: Case of Study on Two Fresh Cut Products. Int J Clin Nutr Diet 6: 149. doi: https://doi.org/10.15344/2456-8171/2020/149

81. Guimarães JER, de la Fuente B, Pérez-Gago MB, Andradas C, Carbó R, et al (2019) Antifungal activity of GRAS salts against Lasiodiplodia theobromae in vitro and as ingredients of hydroxypropyl methylcellulose-lipid composite edible coatings to control Diplodia stem-end rot and maintain postharvest quality of citrus fruit. Int J Food Microbiol 301: 9-18.

82. Grosso AL, Asensio CM, Grosso NR, Nepote V (2020) Increase of walnuts' shelf life using a walnut flour protein-based edible coating. LWT 118 108712.

83. Sánchez-González L, Pastor C, Vargas M, Chiralt A, González-Martínez C, et al. (2011) Effect of hydroxypropylmethylcellulose and chitosan coatings with and without bergamot essential oil on quality and safety of coldstored grapes, Postharvest Biol. Technol 60: 57-63.

84. Sucheta, Chaturvedi K, Sharma N, Yadav SK (2019) Composite edible coatings from commercial pectin, corn flour and beetroot powder minimize post-harvest decay, reduces ripening and improves sensory liking of tomatoes. Int J Biological Macromolecules 133: 284-293.

85. Guerreiro AC, Gago CML, Faleiro ML, Miguel MGC, Antunes MDC, et al (2015) The use of polysaccharide-based edible coatings enriched with essential oils to improve shelf-life of strawberries. Postharvest Biol Technol 110: 51-60.

86. Guerreiro AC, Gago CML, Faleiro ML, Miguel MGC, Antunes MDC, et al. (2017) The effect of edible coatings on the nutritional quality of 'Bravo de Esmolfe' fresh-cut apple through shelf-life. LWT 75: 210-219.

\section{This article was originally published in a special issue}

Functional Foods and Nutraceuticals: Their Role in Disease Prevention

\section{Handled by Editors:}

Prof. Luciana Mosca (Lead Specail Issue Editor)

Department of Biochemical Sciences

University of Rome "La Sapienza"

Italy

Dr. Ilaria Peluso

Food and Nutrition Center

Agricultural Research Council (CRA-NUT)

Italy

Dr. Alessia Baseggio Conrado

Photobiology Unit at the Cancer Division

University of Dundee

United Kingdom

Dr. Anna Scotto D'abusco

Department of Biochemical Sciences

Sapienza University of Rome

Italy 